TAPROBANICA, ISSN 1800-427X. April, 2011. Vol. 03, No. 01: pp. 38-41, 1 pl.

(C) Taprobanica Private Limited, Jl. Kuricang 18 Gd.9 No.47, Ciputat 15412, Tangerang, Indonesia.

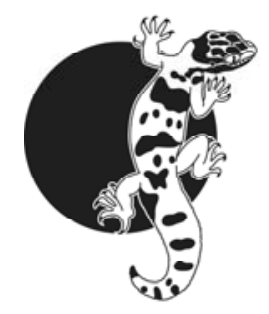

\title{
MUGGER CROCODILE (Crocodylus palustris Lesson, 1831) PREYS ON A RADIATED TORTOISE IN SRI LANKA
}

Sectional Editor: John Rudge

Submitted: 28 June 2011, Accepted: 29 July 2011

Mahesh C. De Silva ${ }^{1}$, A. A. Thasun Amarasinghe ${ }^{2}$, Anslem de Silva ${ }^{3}$ and D. M. S. Suranjan Karunarathna ${ }^{4}$

\footnotetext{
${ }^{1}$ The Young Zoologists’ Association, Department of National Zoological Gardens, Dehiwala 10350, Sri Lanka

${ }^{2}$ Komunitas Konservasi Alam Tanah Timur, Jl. Kuricang 18 Gd.9 No.47, Ciputat 15412, Tangerang, Indonesia E-mail: thasun.tanahtimur@gmail.com

${ }^{3}$ Amphibia and Reptile Research Organization of Sri Lanka, 15/1, Dolosbage Road, Gampola, Sri Lanka

E-mail: kalds@sltnet.lk

${ }^{4}$ Nature Exploration \& Education Team, No: B-1 / G-6, De Soysapura, Morauwa 10400, Sri Lanka

E-mail: dmsameera@gmail.com
}

\begin{abstract}
The Mugger crocodile is the second largest crocodile in Sri Lanka. Recently we observed a Mugger attacking an unidentified radiated tortoise. The body morphology and colouration of this particular tortoise appeared different to the native Star tortoise widely distributed in the country. Thus, the possibility of an escaped or released exotic pet is discussed.
\end{abstract}

Key words: Sri Lanka, Crocodylus palustris, Geochelone elegans, Stigmochelys pardalis, feeding

\section{Introduction}

The Mugger crocodile, Crocodylus palustris is the second largest reptile in Sri Lanka (Deraniyagala, 1953), living in freshwater streams, rivers, canals, tanks and even in hyper-saline estuaries (Deraniyagala, 1930; de Silva, 2010). Currently, the Mugger is categorized as a vulnerable species (IUCN, 2011) and protected by the Fauna and Flora protection ordinance (Act no: 44 of 1964) in Sri Lanka. The Mugger crocodile is also found in India, Pakistan, Bangladesh, Nepal and Iran (Das and de Silva, 2011). Muggers take a wide range of prey (Alderton, 2004; Santiapillai \& de Silva, 2001;
Vyas, 2010). The principal diet of the species is insects, crabs, shrimps, fish, frogs, terrapins, other reptiles, small mammals, monkeys, deer, sambars, buffalos, and occasionally humans (Deraniyagala, 1939; Vyas, 1993; Wilson, 1971; de Silva, 2010). Here we report on the attack strategy of a Crocodylus palustris which took place at Bundala National Park (BNP) and details of the radiated tortoise that was attacked.

Observation (see plate 4: figs. A-P)

On $2^{\text {nd }}$ May 2011, we observed an adult tortoise at 
11:40 hr. in the Bundala National Park (BNP), southern Sri Lanka. The animal most closely fitted the description of the Star tortoise, Geochelone elegans and had a straight carapace length of around $30 \mathrm{~cm}$. The weather was bright and sunny but the surrounding water bodies were full due to five earlier days of heavy rains. The soil was dry. The tortoise was first seen from a distance of $20 \mathrm{~m}$. and it was about 2 meters from the tank's edge. This particular tank is known as "Palugaswala (Pathiraja road)" (which is about $50 \mathrm{~m}$ long and 30 $m$ wide and elliptic in shape). The tortoise was feeding on vegetation and was looking towards the tank. A Canon 7D camera with $400 \mathrm{~mm}$. lens was used to take photographs. Eight people, including one official from the BNP, witnessed the episode.

Around 11:50 hr. a Mugger (total length about 2.5 $\mathrm{m})$ appeared at the water surface about $4 \mathrm{~m}$ away from the tortoise and $2 \mathrm{~m}$ away from the water's edge. Within 3 minutes the crocodile had edged slowly to the land and suddenly grabbed the tortoise. The crocodile caught the tortoise from its anterior carapace dorso-ventrally. Just after catching the tortoise the crocodile went back to the water to around $10 \mathrm{~m}$ from the bank with the tortoise in its mouth (Pl. 4, Fig. A). Then the crocodile dived and disappeared. After about 30 minutes at 12:25 hr. the tortoise re-surfaced (Pl. 4, Fig. B). The tortoise appeared weak, possibly injured by the crocodile attack and moved slowly towards the land. This movement was more floating than active swimming. At 12:31 hr. the tortoise reached the bank (Pl. 4, Fig. C) without seemingly attracting the crocodile.

Suddenly the crocodile re-appeared at the bank from underneath the water (Pl. 4, Fig. D). It approached the tortoise quickly and tried to grab virtually the entire tortoise a number of times. However it failed in all attempts, due to the movements of the tortoise and the shape of the carapace (Pl. 4, Fig. E-I). The tortoise was turned upside down and it tried to right itself but failed due to the mud on the bank (Pl. 4, Fig. J). Surprisingly, considering the crocodile's huge jaws and powerful bites, we did not observe any damage to the carapace of the tortoise. The crocodile then moved back about $50 \mathrm{~cm}$ and remained still for a few seconds (Pl. 4, Fig. K). It then jumped forward and this time grabbed the tortoise from one end of the carapace (Pl. 4, Fig. L-N). After this the crocodile went back into the water about $10 \mathrm{~m}$ from the bank, waited for a few minutes on the surface (Pl. 4, Fig. $\mathrm{O}, \mathrm{P}$ ) and then dived and disappeared at 12:34 hr.
We waited there until 1:22 hr. but did not see either the crocodile or the tortoise again.

\section{Discussion}

There are several significant aspects to this episode. Firstly, we did not observe any damage to the carapace of the tortoise, even after the crushing force of the crocodile bite. Secondly, we were surprised how the tortoise survived around 30 minutes under water. According to Bonin et al. (2006), Das (1995) and Jayakar \& Spurway (1996), Star Tortoises cannot swim and dive in water. Thirdly, the radiated tortoise in this instance coming towards the tank and feeding on the vegetation at noon in the hot climate of BNP is uncommon. The more usual active foraging times of the land tortoise are in the morning (06:00 to 08:00 hr.) and at dusk when the sun is not hot (de Silva, 2003). Possibly it could have come to drink water. Finally, the distinct carapace, body morphology and colouration of this particular tortoise was quite different to the common Star tortoise (Geochelone elegans), which is the native species widely distributed in the dry zone lowlands of Sri Lanka (Deraniyagla, 1939 \& 1953; de Silva, 2003 \& 2006) and common in the BNP. Based on the photograph of this animal (Fig. 1) it has been considered by some as Stigmochelys pardalis (personal comm., Indraneil Das and Andy Highfield, July, 2011). It is also possible that it may be an aberrant form of Geochelone elegans (personal comm., Uwe Fritz, July, 2011) or possibly a different foreign species.

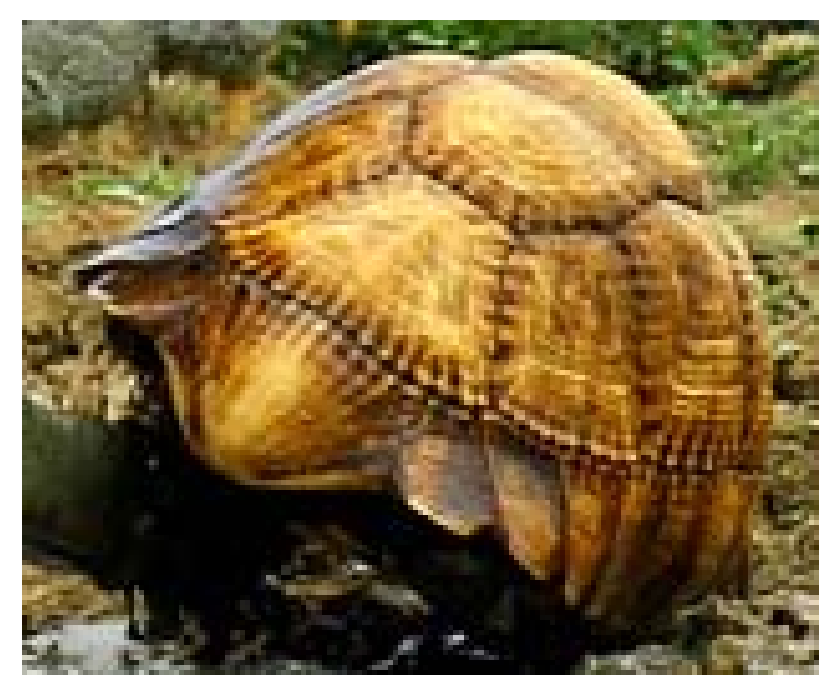

Fig. 1: The land tortoise consumed by the Mugger crocodile

Scanning through the available literature we see an interesting report by Amyrald Haly (the first Director of the Colombo Museum) of purchasing a 'stared tortoise' from Wellawatte (Colombo) - the 
person who had collected it stated that it was not the first time he had seen specimens of this particular species. Haly (1894) assumes that this could have been a foreign species that had escaped from captivity or been released after keeping for some time. Haly (1892) also reports of securing a Star Tortoise from a grass field in Cinnamon Gardens (virtually central Colombo). This could have been an escaped pet or one that had been brought and released after some time. Furthermore, we could assume that Europeans who lived in Sri Lanka during the colonial period (up to 1948) would have brought pet tortoises and released them after some time.

We have to consider another important fact. That is that many pet traders in the country have been importing the American Red-eared Slider (Trachemys scripta) which is considered as one of the top invaders into many ecosystems in the world and is now known from water bodies in Colombo and its suburbs (de Silva, 1996). Thus, there is a possibility that the same pet traders could have also imported other radiated tortoises. However, due to legal actions taken by the Department of Wildlife Conservation, many people have handed over their pet Star tortoise collections to the Department of National Zoological Gardens (de Silva, 2003) or released them in various parks or forests. It is highly possible that there could be some exotic radiated tortoises in the wild in Sri Lanka.
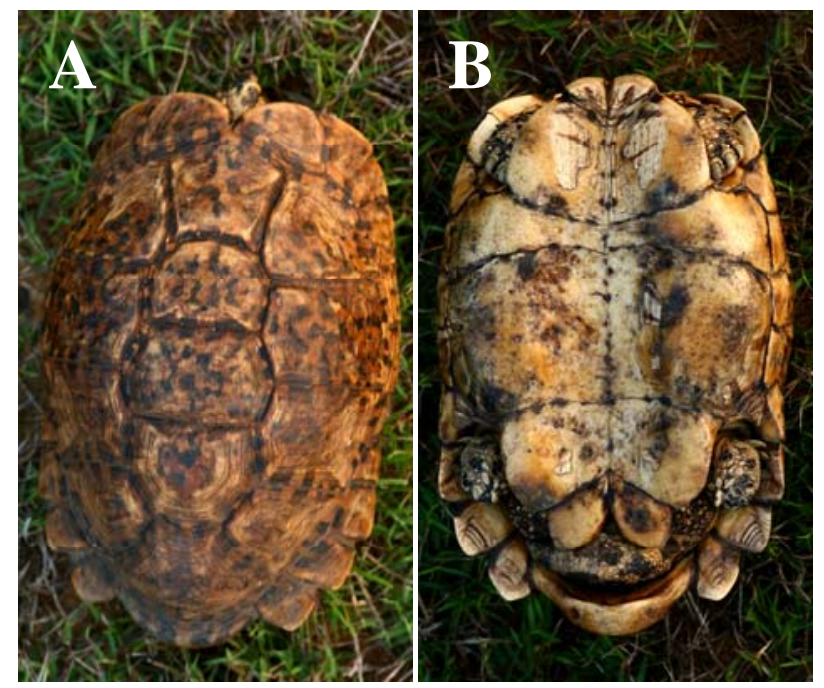

Fig. 2: Geochelone cf. elegans from Puttalam; A. dorsal view, B. ventral view (Photo: Vimukthi Weeratunga)

As regards G. elegans, recent molecular work on it from the Indian subcontinent has shown a strong genetic diversity (Gaur et al., 2006). Vyas (2009) has even suggested three discrete sub-populations of G. elegans, two from mainland India and one from Sri Lanka. See the cover image of this journal and Fig. 2 for a tortoise in an isolated population in Puttalam (northwest Sri Lanka).

For comparison, a typical morph of the Star Tortoise from Puttalam and a Leopard Tortoise from Botswana are photographed in Fig. 3 and Fig. 4 respectively; notice the difference in carapace morphology, as well as markings. Thus, we suggest that a molecular study of the Sri Lankan G. elegans from the south, east, north-central, north-west and the north of the country should be conducted.

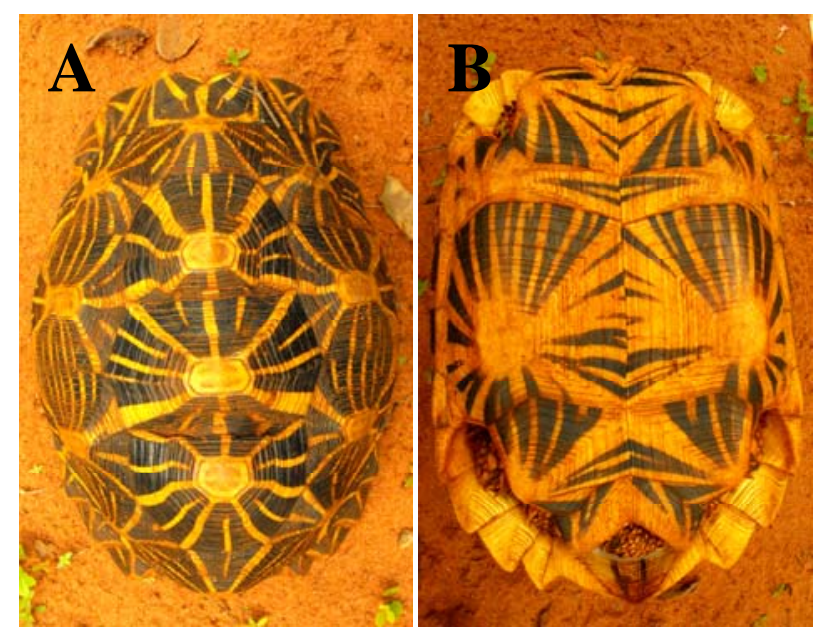

Fig. 3: Typical morph of Star tortoise, Geochelone elegans from Puttalam; A. dorsal view, B. ventral view (Photo: Sameera Karunarathna)

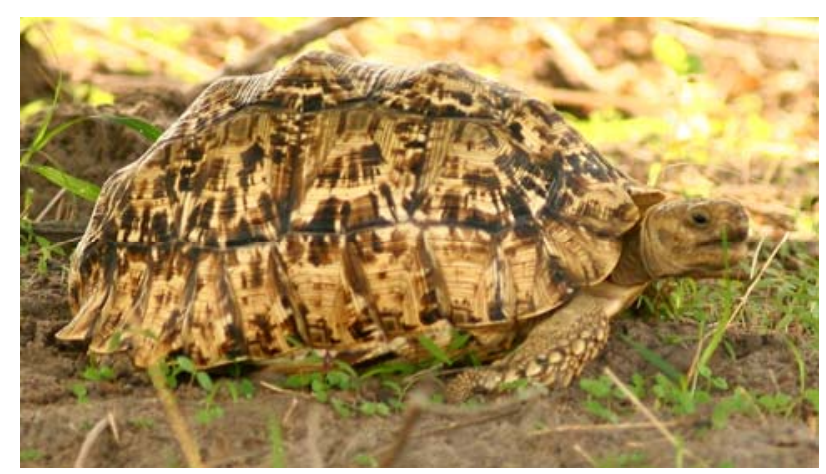

Fig. 4: Leopard tortoise, Stigmochelys pardalis from Botswana (Photo: Lee Harding)

\section{Acknowledgements}

We would like to thank Lee Harding and Ralf Sommerlad for reviewing the manuscript. Indraneil Das, Andy Highfield and Uwe Fritz are acknowledged for personal communications. Also the first author thanks Ajith Nishantha and the staff of BNP. Finally Vimukthi Weeratunga and Lee Harding are thanked for photographs. 


\section{Literature cited}

Alderton, D., 2004. Crocodiles and Alligators of the World. Fact on File, Inc and Cassell Illustrated, London: 190.

Bonin, F., B. Devaux, and A. Dupre, 2006. Turtles of the world. The Johns Hopkins University Press, USA: 416.

Das, I., 1995. Turtles and Tortoise of India. WWF India and the Oxford University Press, Bombay: 176.

Das, I. and A. de Silva, 2011. A photographic guide to snakes and other reptiles of Sri Lanka. New Holland, UK: 144.

Deraniyagala, P. E. P., 1930. The Crocodiles of Ceylon. Spolia Zeylanica, 16 (1): 89-95.

Deraniyagala, P. E. P., 1939. The Tetrapod reptiles of Ceylon; Testudinates and Crocodilians - Vol 1, National Museums of Sri Lanka, Colombo: 412.

Deraniyagala, P. E. P., 1953. A Colored Atlas of some vertebrates from Ceylon, Tetrapod Reptilia - Vol 2, National Museums of Sri Lanka, Colombo.

de Silva, A., 1996. Proposed action plan: conservation, restoration and management of the Testudines and their habitats in Sri Lanka. Global Environmental Facility Programme: 28.

de Silva, A., 2003. The biology and status of the star tortoise in Sri Lanka. Ministry of Environment and Natural Resources: 100

de Silva, A., 2006. Current status of the Reptiles of Sri Lanka, In: Bambaradeniya, C. N. B. (Ed.). Fauna of Sri Lanka: Status of Taxonomy, Research and Conservation. IUCN Sri Lanka: 134-163.

de Silva, A., 2010. Crocodiles of Sri Lanka: preliminary assessment of their status and the human crocodile conflict situation. (Report submitted after fulfillment of the project to Mohamed Bin Zeyed Species Conservation Fund) Author, Gampola: 49.

Gaur, A., A. Reddy, S. Annapoorni, B. Satyarebala, and S. Shivaji, 2006. The origin of Indian Star tortoises (Geochelone elegans) based on nuclear and mitochondrial DNA analysis: A story of rescue and repatriation. Conservation Genetics, 7 (2): 231-240.

Haly, A., 1892. Reptiles. In: The Ceylon Administrative Reports for the year 1891. Government Press. Colombo: 15.
Haly, A., 1894. Reptiles. In: The Ceylon Administrative Reports for the year 1893. Government Press. Colombo: 13.

IUCN, 2011. IUCN Red List of Threatened Species. www.iucnredlist.org. downloaded on $06^{\text {th }}$ July 2011.

Jayakar, S. K. and H. Spurway, 1996. Contribution to the biology of the Indian stared tortoise, Testudo elegans Schoepff. Journal of the Bombay Natural History Society, 63 (1): 83-114.

Santiapillai, C. and M. de Silva, 2001. Status, distribution and conservation of crocodiles in Sri Lanka. Biological Conservation, 97 (3): 305-318.

Vyas, R., 1993. Recent cases of man-eating by the mugger (Crocodylus palustris) in Gujarat State. Hamadryad, 18: 48-49.

Vyas, R., 2009. The Status of North-Western Populations of Star Tortoise (Geochelone elegans). Chapter 11. IN: Vasudevan, K. (Ed.). Freshwater Turtles and Tortoises of India. ENVIS Bulletin: Wildlife and Protected Areas, Vol. 12 (1). Wildlife Institute of India, Dehradun, India.

Vyas, R., 2010. Mugger (Crocodylus palustris) population in and around Vadodara City, Gujarat State, India. Russian Journal of Herpetology, 17 (1): 43-50.

Wilson, C., 1971. Crocodiles!. Loris, 12 (3): 151-152. 


\section{PLATE 04}
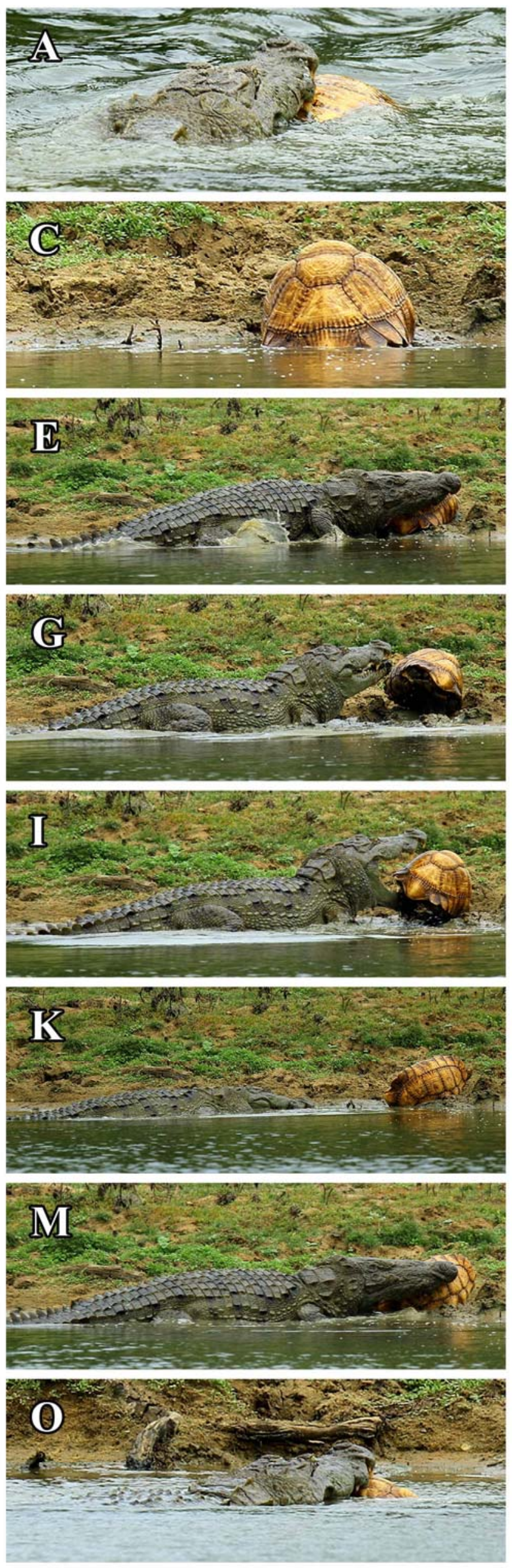

B

\section{nex 4y}
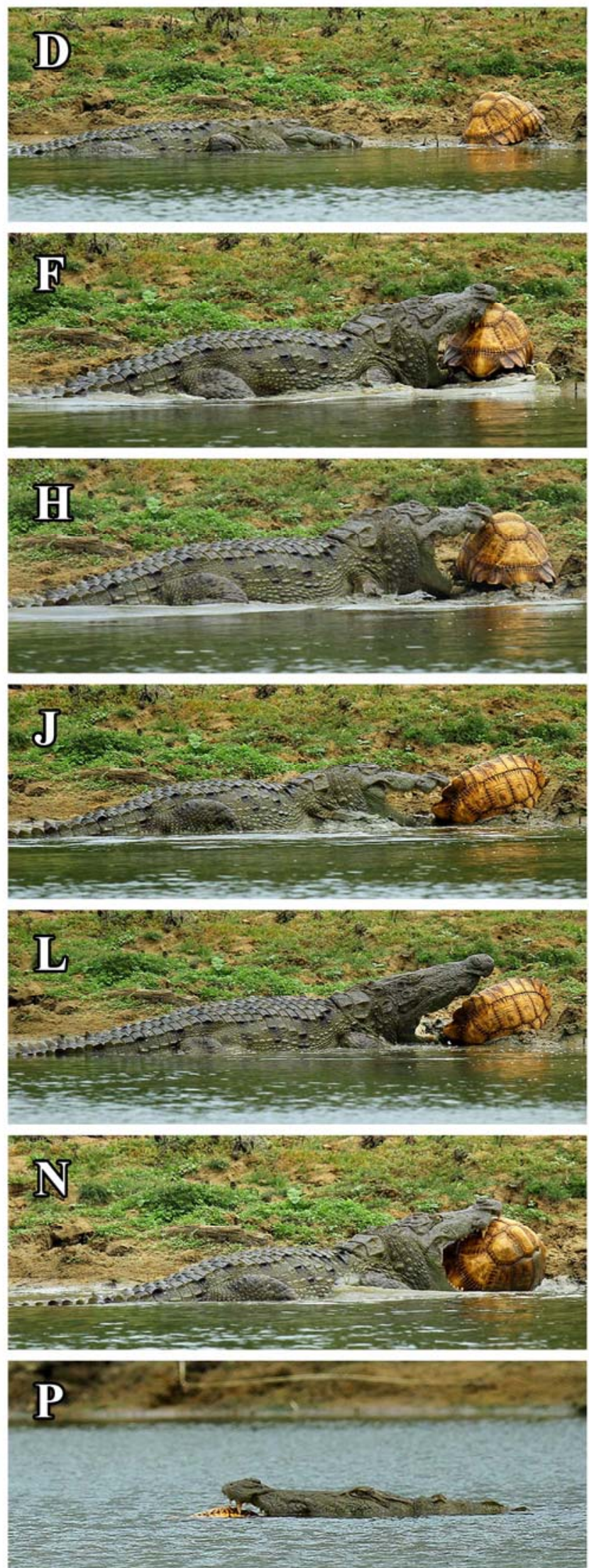